\title{
Differentiation and Transmigration of CD4 T Cells in Neuroinflammation and Autoimmunity
}

\author{
Sandip Ashok Sonar and Girdhari Lal* \\ National Centre for Cell Science, Pune, India
}

OPEN ACCESS

Edited by:

Amit Awasthi,

Translational Health Science and

Technology Institute, India

Reviewed by:

Manu Rangachari,

Laval University, Canada

Markus Kleinewietfeld,

VIB-UGent Center for Inflammation

Research (IRC), Belgium

*Correspondence:

Girdhari Lal

glal@nccs.res.in

Specialty section:

This article was submitted

to T Cell Biology,

a section of the journal

Frontiers in Immunology

Received: 31 August 2017

Accepted: 16 November 2017

Published: 29 November 2017

Citation:

Sonar SA and Lal G (2017)

Differentiation and Transmigration of

CD4 T Cells in Neuroinflammation

and Autoimmunity.

Front. Immunol. 8:1695.

doi: 10.3389/fimmu.2017.01695
$\mathrm{CD}^{+} \mathrm{T}$ cells play a central role in orchestrating protective immunity and autoimmunity. The activation and differentiation of myelin-reactive CD4 ${ }^{+} T$ cells into effector (Th1 and Th17) and regulatory (Tregs) subsets at the peripheral tissues, and their subsequent transmigration across the blood-brain barrier (BBB) into the central nervous system (CNS) parenchyma are decisive events in the pathogenesis of multiple sclerosis and experimental autoimmune encephalomyelitis. How the Th1, Th17, and regulatory Tregs transmigrate across the BBB into the CNS and cause CNS inflammation is not clearly understood. Studies with transgenic and gene knockout mice have unraveled that Th1, Th17, and Tregs play a critical role in the induction and resolution of neuroinflammation. However, the plasticity of these lineages and functional dichotomy of their cytokine products makes it difficult to understand what role CD4+ $\mathrm{T}$ cells in the peripheral lymphoid organs, endothelial BBB, and the CNS parenchyma play in the CNS autoimmune response. In this review, we describe some of the recent findings that shed light on the mechanisms behind the differentiation and transmigration of $\mathrm{CD}^{+}{ }^{+} \mathrm{T}$ cells across the BBB into the CNS parenchyma and also highlight how these two processes are interconnected, which is crucial for the outcome of CNS inflammation and autoimmunity.

Keywords: blood-brain barrier, experimental autoimmune encephalomyelitis, CD4 T cells, neuroinflammation, transendothelial migration

\section{INTRODUCTION}

Homeostasis of central nervous system (CNS) is maintained by various mechanisms operating in both the CNS and the peripheral immune system. Due to the presence of barriers, CNS antigens are not exposed to cells of the peripheral immune system, which ensures a lack of effector immune response to CNS antigens in the steady state (1). However, upon recognition of CNS-derived antigens or cross-reactive microbial antigens, the peripheral $\mathrm{CD} 4^{+} \mathrm{T}$ cells have escaped from the central tolerance, mount a robust immune response, and infiltrate into the CNS. Such infiltration of $\mathrm{CD} 4^{+} \mathrm{T}$ cells causes $\mathrm{CNS}$ autoimmune diseases such as multiple sclerosis (MS) and experimental

\footnotetext{
Abbreviations: APCs, antigen-presenting cells; BBB, blood-brain barrier; CFA, complete Freund's adjuvant; CSF, cerebrospinal fluid; CNS, central nervous system; EAE, experimental autoimmune encephalomyelitis; ECs, endothelial cells; ICAM-1, intercellular adhesion molecule 1; ILCs, innate lymphoid cells; LFA-1, lymphocyte function-associated antigen $1 ; \mathrm{MOG}_{35-55}$, myelin oligodendrocyte glycoprotein peptide amino acid 35-55; MS, multiple sclerosis; TEM, transendothelial migration; Tregs, Foxp3+ regulatory T cells; Tr1 cells, T regulatory 1 cells; VCAM-1, vascular cell adhesion molecule 1; VLA-4, very late antigen 4.
} 
autoimmune encephalomyelitis (EAE) (2). MS is a human autoimmune demyelinating disease of the CNS characterized by massive infiltration of inflammatory lymphocytes and myeloid cells into the brain and spinal cord, leading to demyelination, axonal damage, and loss of neuromuscular functions (3). Most of the clinical and pathological features of MS are recapitulated in the animal model, EAE, which is one of the important models used to study CNS inflammatory diseases. EAE is also used for evaluating the efficacy of several therapeutic strategies to control neuroinflammation and autoimmunity (3).

\section{ACTIVATION OF MYELIN-SPECIFIC CD4 ${ }^{+}$ T CELLS DURING CNS INFLAMMATION AND AUTOIMMUNITY}

There is a long-standing hypothesis in the field that the activation of myelin-specific $\mathrm{CD} 4^{+} \mathrm{T}$ cells requires a trigger from some environmental factors (4). EAE is induced by activating myelinreactive lymphocytes through peripheral immunization with myelin antigens. EAE can also be induced in susceptible animal hosts either by subcutaneous immunization (s.c.) with myelin antigens emulsified in complete Freund's adjuvant (CFA) or by the adoptive transfer of in vitro-activated myelin-specific CD $4^{+}$ $\mathrm{T}$ cell subsets such as Th1 and Th17 $(5,6)$. Among the various myelin proteins, proteolipid protein, myelin basic protein, and myelin oligodendrocyte glycoprotein (MOG), and their corresponding immunodominant peptides have been extensively used to induce EAE in different rodent hosts $(2,5)$. However, this also requires administration of pertussis toxin, highlighting the importance of environmental factors in the development of CNS pathology $(7,8) \cdot \mathrm{CD}^{+}$and $\mathrm{CD}^{+} \mathrm{T}$ cells that have low affinity/avidity for myelin antigens, escape thymic selection, and are localized mainly to the secondary lymphoid organs, where they remain in the tolerant state under homeostatic conditions (9). The subcutaneous deposition of myelin peptide emulsion attracts and activates professional antigen-presenting cells (APCs), such as dendritic cells, macrophages, and B cells, at the site of injection. These APCs take up the antigens and migrate to the draining lymph nodes, where they process and present antigenic peptides to the T lymphocytes. Immunization (s.c.) of $\mathrm{C} 57 \mathrm{BL} / 6$ mice with $\mathrm{MOG}_{35-55}-\mathrm{CFA}$ emulsion along with intravenous pertussis toxin were found to induce antigenspecific Th1 and Th17 cells in the draining lymph nodes, and at the same time limit the regulatory $\mathrm{T}$ (Treg) number and function (7, 10). Interestingly, T-cell receptor (TCR)-transgenic mice, such as $2 \mathrm{D} 2$ mice in which $\mathrm{CD} 4^{+} \mathrm{T}$ cells are engineered to express $\mathrm{MOG}_{35-55}$-specific TCR, develop spontaneous CNS autoimmunity (11), suggesting the importance of CD4 ${ }^{+} \mathrm{T}$ cells in EAE. By using several knockout and transgenic mice, molecules involved in the TCR and costimulatory and coinhibitory signaling in the activation, proliferation, and differentiation of myelin-specific $\mathrm{CD}^{+}{ }^{+} \mathrm{T}$ cells have been evaluated. Furthermore, several members of the TNF-receptor superfamily critically regulate the $\mathrm{CD}^{+} \mathrm{T}$ cell response both in the secondary lymphoid organs and inflamed CNS and perturb the pathology of EAE (12).

\section{DIFFERENTIATION OF MYELIN-SPECIFIC CD4 ${ }^{+}$T CELLS}

The naive $\mathrm{CD}^{+} \mathrm{T}$ cells, when stimulated by myelin APCs and specific cytokines, differentiate into various effector and regulatory lineages (Figure 1). Th1 cells secrete IFN- $\gamma$ and TNF- $\alpha$ and are critical for controlling intracellular pathogens and induction of delayed-type hypersensitivity response. Excess activation of Th1 is involved in many organ-specific inflammations, including MS and EAE (13). In the presence of a strong TCR signal, IL-12/ STAT4 and IFN- $\gamma /$ STAT1 signaling induces the Th1-specific transcription factor T-bet, which amplifies IFN- $\gamma /$ STAT1/T-bet signaling and drives Th1 differentiation $(14,15)$. Furthermore, T-bet cooperatively interacts with other transcription factors such to RUNX1, RUNX3, GATA3, IRF4, and BCL6 to inhibit the differentiation of alternative $\mathrm{CD} 4^{+} \mathrm{T}$ cell subsets $(16,17)$. Mice deficient in Th1-associated factors such as T-bet and STAT4 are resistant to the development of EAE (18), whereas IFN- $\gamma^{-/-}$, IFN$\gamma \mathrm{R}^{-/-}$, and STAT1 $1^{-1-}$ mice develop more severe EAE (19). This suggests that Th1 cells play a critical role in the pathogenesis of EAE and MS through diverse mechanisms.

In humans and mice, various cytokines induces the differentiation of Th17 cells with diverse phenotypes and functions. The conventional Th17 cells generated in the presence of TGF- $\beta 1$ and IL- 6 are non-pathogenic during EAE, being involved in the maintenance of mucosal surface homeostasis and anti-bacterial defense $(20,21)$. However, several other factors such as IL-1 $\beta$, IL-23, and TGF- $\beta 3$ have been identified to favor the generation and maintenance of highly pathogenic Th17 cells during EAE (21-24). Mice deficient in IL-23 or IL-23R are completely resistant to the development of $\operatorname{EAE}(23,25)$. Th17 cells that coexpress ROR $\gamma$ t and T-bet and produce both IL-17A and IFN- $\gamma$, are highly pathogenic and preferentially recruited into the CNS, suggesting that T-bet enhances the pathogenicity of Th17 cells $(13,21,26)$. The detailed development, phenotypic, and functional differences between pathogenic and non-pathogenic Th17 cells have been reviewed recently (21). Interestingly, a recent report shows that IL-23 induces a switch from CCR6 to CCR2 usage and controls the development and migration of highly encephalitogenic granulocyte macrophagecolony stimulating factor (GM-CSF)-expressing Th17 cells into the CNS, suggesting that homing receptors and pathogenic functions are imprinted during differentiation (27). It has been shown that IL-12 induces STAT4 signaling and also triggers GM-CSF expression in Th1 cells and promote EAE development (28). Interestingly, GM-CSF-producing Th1-like cells are also found in the cerebrospinal fluid (CSF) of MS patients (29), suggesting that GM-CSF may contribute to the pathogenic function of Th17, IFN- $\gamma$ expressing ex-Th17 and Th1 cells. The chronic inflammatory signals can affect the transcriptional and/ or epigenetic signature and control the plasticity of Th1, Th17, and Tregs in the inflamed CNS and lymphoid organs during EAE (30). The IL-23-induced alternatively activated Th17 $\left(\mathrm{T}-\right.$ bet $^{+} \mathrm{ROR} \gamma \mathrm{t}^{+}$) or ex-Th17 cells that acquire T-bet and IFN- $\gamma$ and express negligible ROR $\gamma \mathrm{t}$ and IL-17 are more pathogenic $(31,32)$. Similarly, transdifferentiation of Th17 into Tregs, and Tregs to effector Th1, Th2, and Th17 cells are also known $(33,34)$. 


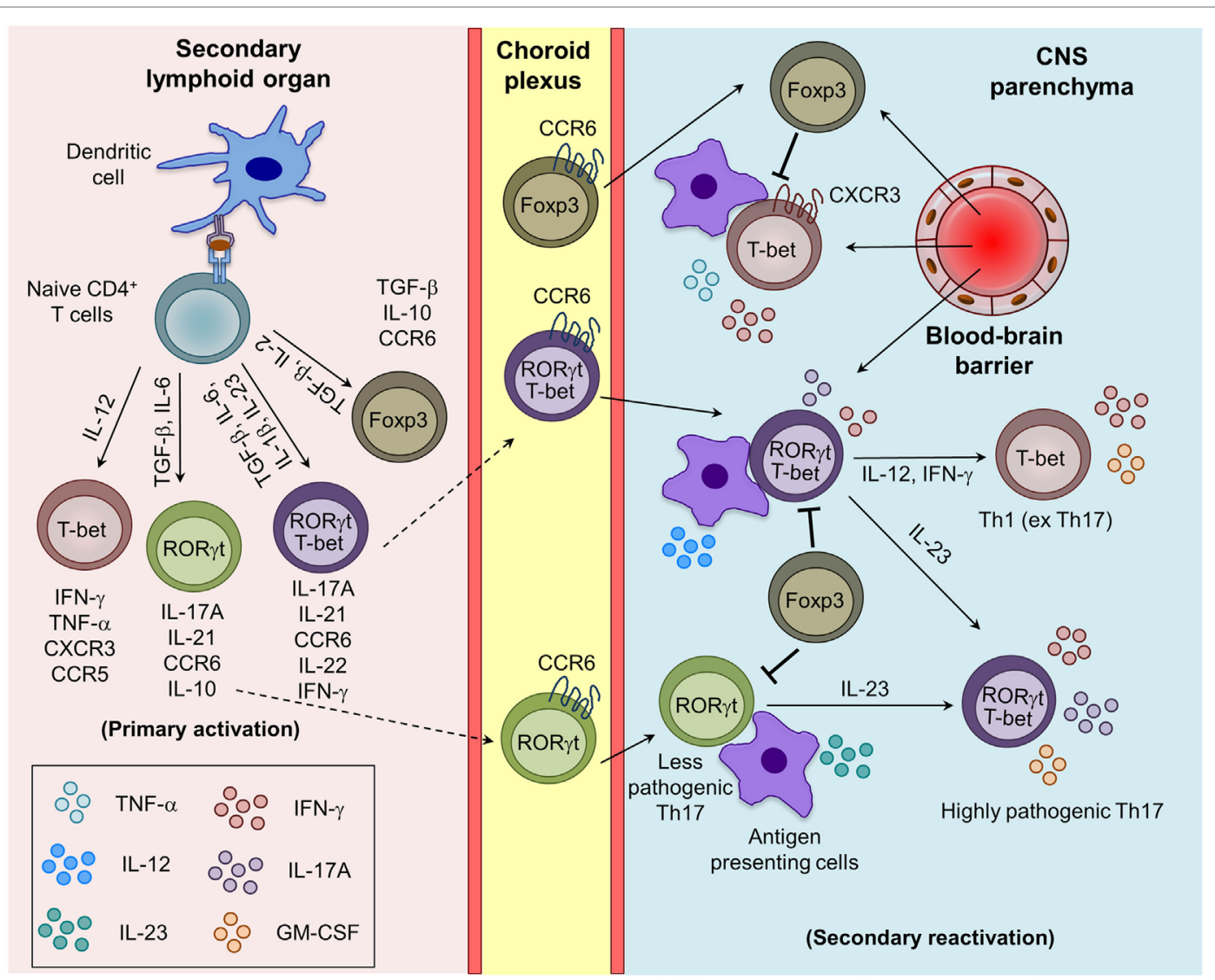

FIGURE 1 | Generation of myelin-reactive effector Th1, Th17, and regulatory iTreg cells and their plasticity in the central nervous system (CNS) parenchyma during experimental autoimmune encephalomyelitis. Upon appropriate myelin antigen presentation, and in the presence of adequate costimulatory molecules and cytokine signaling, naive CD4+ $\mathrm{T}$ cells are activated and give rise to effector (Th1 and Th17) and regulatory (iTreg) T cells. Th17 cells are trafficked into the CNS mainly through the choroid plexus using CCR6-CCL20 interactions, whereas Th1 cells cross the blood-brain barrier mostly using CXCR3-CXCL9/10/11 interactions. The reactivation of the infiltrating Th1 and Th17 cells by the local antigen-presenting cells (APCs) in the CNS boosts the cytokine secretion and pathogenic potential of Th1 and Th17 cells. Under the influence of IL-12 and IL-23 produced by the APCs, Th17 cells acquire the Th1 (ex Th17) and highly pathogenic Th17 (ROR $\mathrm{t}^{+}$T-bet ${ }^{+}$) phenotype.

IL-23-induced phosphorylation and nuclear localization of STAT3/STAT4 heterodimer has been shown to control the generation of encephalitogenic Th1/Th17 cells (35). More studies are needed to understand the minimum essential cytokine stimuli is require to generate highly pathogenic Th17 cells and that may help in designing better therapeutic strategies to control the inflammation and autoimmunity.

Regulatory $\mathrm{T}$ cells are suppressive in nature and known to control the myelin-reactive $\mathrm{CD} 4^{+}$effector $\mathrm{T}$ cell response and are therefore pivotal in regulating CNS inflammation during EAE $(36,37)$. Based on their developmental pathways, they are classified as natural Tregs (nTrgs; thymic-derived) or induced Tregs (iTregs; extrathymic-derived) $(34,38,39)$. nTregs express Foxp3, a lineage-defining transcription factor, and CD25 (IL-2R $\alpha$ ) during their development in the thymus. iTregs are generated from naive $\mathrm{CD} 4^{+} \mathrm{T}$ cells in the presence of TGF- $\beta$ in the peripheral lymphoid tissue, which induces the expression of Foxp3 through STAT5 activation $(40,41)$. In both humans and mice Tregs, Foxp3 required for their suppressive capacity, and its deficiency is associated with the development of spontaneous autoimmunity
$(38,39,42)$. Tregs employ diverse contact-dependent (expression of CTLA4, FasL, and LAG3) and contact-independent (secretion of TGF- $\beta$ and IL-10, deprivation of IL-2, and ectonucleotidases CD39/CD73-mediated conversion of extracellular inflammatory ATP/ADP into adenosine) mechanisms to inhibit the functions of myelin-reactive pathogenic $\mathrm{T}$ cells and other effector myeloid cells (43). The generation of myelin antigen-reactive $\mathrm{CD} 4^{+} \mathrm{T}$ cell subsets and the plasticity of Th1 and Th17 cells in inflamed CNS during EAE are depicted in Figure 1.

Other subsets of $\mathrm{CD} 4^{+} \mathrm{T}$ cells, such as Th9, $\mathrm{T}$ follicular helper (Tfh), $\mathrm{T}$ follicular regulatory, and $\mathrm{T}$ regulatory $1(\operatorname{Tr} 1)$, are also reported to contribute to the development of neuroinflammation and autoimmunity. The adoptive transfer of MOG-specific Th9 cells is known to induce EAE in C57BL/6 recipients (44). Moreover, IL-9 is required for mast cell activation, which has previously been shown to degrade myelin during CNS inflammation (45). Thh cells, which are mainly involved in the regulation of germinal center reaction, are also hypothesized to participate in the pathogenesis of MS and EAE by virtue of their ability to help in the formation of ectopic lymphoid follicles 
in the inflamed CNS (46). Tr1 cells which are differentiated in vitro by culturing in the presence of TGF- $\beta$ plus IL-27 show the Foxp $3^{-}$IL $-10^{+}$IFN- $\gamma^{+}$phenotype. Tr1 cells are known to play a significant role in the development of transplantation tolerance (47), but their exact role in EAE is not known. However, IL-27R $\alpha^{-1-}$ mice are hypersusceptible to the development of EAE, possibly because of a lack of IL-27-mediated control of Th17, as well as the absence of $\operatorname{Tr} 1$-mediated suppression (48). There are several Th1- and Th17-associated molecules, which play an important role in the pathogenesis of EAE, and their deficiency affects the severity of the disease (Table 1).

\section{MIGRATION OF MYELIN-SPECIFIC CD4 ${ }^{+}$ T CELLS INTO THE CNS DURING INFLAMMATION AND AUTOIMMUNITY}

Various cellular and molecular interactions help in maintaining the blood-brain barrier (BBB) integrity and immune quiescence into the CNS. It has been reported that astrocytes secrete Sonic hedgehog and endothelial cells (ECs) express Hedgehog receptors, and interaction of these receptor ligand promote the $\mathrm{BBB}$ formation and integrity (62). Migration of immune cells into the CNS parenchyma is a highly regulated process which occurs at various anatomical sites of the CNS, such as at the choroid plexus of the blood-CSF barrier, as well as across the BBB at postcapillary venules. The transmigration across the $\mathrm{BBB}$ is a very dynamic process and depends on a series of sequential and interdependent steps constituting tethering and rolling of immune cells, chemokine-induced activation, followed by polarization, crawling, the arrest of immune cells, and finally diapedesis of cells across the BBB ECs.
Intravital microscopic analysis of encephalitogenic $\mathrm{T}$ cell interactions with inflamed brain and spinal cord microvessels have revealed that the P-selectin glycoprotein ligand (PSGL-1)$\mathrm{P} / \mathrm{E}$-selectin interaction mediates the initial rolling and tethering of $\mathrm{CD}^{+}$and $\mathrm{CD}^{+} \mathrm{T}$ cells (63). However, deficiencies of E- and P-selectin or PSGL-1 do not protect mice from EAE $(64,65)$, suggesting the redundant roles of these molecules during neuroinflammation. Followed by tethering, the $\alpha_{4} \beta_{1}$-integrin on $\mathrm{T}$ cells interacts with endothelial vascular cell adhesion molecule 1 (VCAM-1) and is required for firm adhesion of T cells (66). Further studies are needed to clarify whether encephalitogenic $\mathrm{T}$ cells use alternative molecules for rolling and tethering onto the inflamed BBB.

The $G$ protein-coupled receptors, such as chemokines and eicosanoids displayed on the luminal surface of the BBB ECs, trigger the integrin activation that leads to $\mathrm{T}$ cell firm arrest on the vascular endothelium. During EAE, ECs are shown to express CCL2, CCL19, and CCL21, which mediate firm arrest of CCR2 ${ }^{+}$monocytes and DCs, and $\mathrm{CCR} 7^{+} \mathrm{CD} 4^{+} \mathrm{T}$ cells (67). However, the exact role of these interactions in the transendothelial migration (TEM) of encephalitogenic $\mathrm{CD} 4^{+} \mathrm{T}$ cells remains to be determined. Mice that overexpress CCL19, CCL21, or CXCL10 molecules in the CNS do not show hypersusceptibility to the EAE development $(68,69)$, suggesting that the functions of these chemokine interactions are tightly regulated. Chemokine receptor-induced signaling leads to a conformational change in the integrin molecules on $\mathrm{CD} 4^{+} \mathrm{T}$ cells, and which causes an increase in their affinity for their cognate ligands. Inflamed endothelial vessels in the CNS parenchyma upregulate the expression of the intercellular adhesion molecule 1 (ICAM-1) and VCAM-1, and their respective ligands, $\alpha_{\mathrm{L}} \beta_{2}$ [lymphocyte function-associated antigen 1 (LFA-1)], and $\alpha_{4} \beta_{1}$ [very late

TABLE 1 | Susceptibility and severity of experimental autoimmune encephalomyelitis (EAE) in various mouse strains.

\begin{tabular}{|c|c|c|c|c|}
\hline Mouse strains & EAE type & Pathology of the disease & Disease susceptibility & Reference \\
\hline IL-12p35-/- & Classical & Mononuclear cells in the spinal cord & Susceptible & $(27,49)$ \\
\hline IL-12p40-/- & & & Resistant & $(27,49)$ \\
\hline IL-12R $\beta 2^{-/-}$ & Classical & Mononuclear cells in the spinal cord & Severe EAE & (50) \\
\hline STAT1-/- & Atypical & Macrophage and neutrophils in the brain and spinal cord & Hypersusceptible & $(18,19)$ \\
\hline STAT1-/-.T-bet ${ }^{-/-}$ & Atypical & Macrophage and neutrophils in the brain and spinal cord & Less severe EAE & $(15,18)$ \\
\hline T-bet ${ }^{-/-}$ & & & Resistant & $(13,18)$ \\
\hline STAT4 ${ }^{-/-}$ & Classical & Reduced infiltration in the spinal cord & Resistant & $(35,51)$ \\
\hline STAT6 $^{-/-}$ & Classical & Mononuclear cells in the spinal cord & Severe EAE & (51) \\
\hline TNF- $\alpha^{-/-}$ & Classical & Mononuclear cells in the spinal cord & Delayed but comparable severity & $(52)$ \\
\hline TNFR- $1^{-/-}$ & Classical & Mononuclear cells in the spinal cord & Less severe EAE & (53) \\
\hline TNFR-2 ${ }^{-/-}$ & Classical & Mononuclear cells in the spinal cord & Severe EAE & (53) \\
\hline TNFR1/2 $2^{-/-}$ & Classical & Mononuclear cells in the spinal cord & Severe EAE & (53) \\
\hline IFN- $\gamma^{-/-}$ & Atypical & Predominantly neutrophils in the brain-stem and cerebellum & Hypersusceptible & (19) \\
\hline $\mathrm{IFN}-\gamma \mathrm{R}^{-/-}$ & Atypical & Predominantly neutrophils in the brain-stem and cerebellum & Hypersusceptible & (54) \\
\hline IL-23p $19^{-/-}$ & & & Completely resistant & $(23,25)$ \\
\hline IL-23R ${ }^{-/-}$ & & & Completely resistant & (55) \\
\hline IL-6- ${ }^{-/-}$ & & & Completely resistant & (56) \\
\hline $\mathrm{GM}^{-\mathrm{CSF}^{-/-}}$ & & & Completely resistant & (57) \\
\hline IL-17A $\mathrm{A}^{-/-}$ & Classical & Mononuclear cells in the spinal cord & Delayed but comparable severity & (58) \\
\hline IL-17F-/- & Classical & Mononuclear cells in the spinal cord & Susceptible & (58) \\
\hline IL-21 & Classical & Mononuclear cells in the spinal cord & Susceptible & $(59,60)$ \\
\hline IL-21R ${ }^{-/-}$ & Classical & Mononuclear cells in the spinal cord & Susceptible & $(59,60)$ \\
\hline $\mid \mathrm{IL}-22^{-/-}$ & Classical & & Susceptible & (61) \\
\hline IL-27R $\alpha^{-/-}$ & Classical & & Hypersusceptible & (48) \\
\hline
\end{tabular}


antigen 4 (VLA-4)] integrins, are expressed on the encephalitogenic $\mathrm{CD}^{+} \mathrm{T}$ cells (70). Multiple investigators have shown that LFA-1-ICAM-1 and VLA-4-VCAM-1 interactions are critically involved in the firm arrest of $\mathrm{CD}^{+} \mathrm{T}$ cells onto the inflamed cerebral vessels or primary brain EC monolayers (71). Moreover, LFA-1-ICAM-1 interactions dictate the polarization and crawling of $\mathrm{CD}^{+} \mathrm{T}$ cells onto the inflamed vessels ECs, but VLA-4-VCAM-1 interactions do not (66). The anti- $\alpha 4$-integrin antibody, natalizumab has been approved for the treatment of relapsing-remitting MS (72). Interestingly, $\alpha_{4} \beta_{1}$-integrinVCAM-1 interaction arrest encephalitogenic Th1 cells onto the spinal cord microvessels, whereas LFA-1-ICAM-1/2 regulates Th17 adhesion to the endothelial barrier in the brain. This suggests that Th1 cells preferentially use $\alpha 4$-integrin, whereas Th17 transmigration across the $\mathrm{BBB}$ is $\alpha 4$-integrin independent $(73,74)$. Other cell adhesion molecules such as activated leukocyte cell adhesion molecule and melanoma cell adhesion molecule (MCAM) are also known to regulate transmigration of the CD4 ${ }^{+}$ and $\mathrm{CD}^{+} \mathrm{T}$ cells and CNS autoimmunity (75-77). The MCAM expression in lymphocytes are associated with GM-CSF, IL-22, and IL-17A/IFN- $\gamma$ coproducing Th17 cells (75), and antibodymediated blocking of MCAM controls the CNS autoimmunity $(75,77)$. Recently, $\alpha_{v} \beta_{3}$-integrin has been shown to control Th17 migration into the CNS, and a lack of $\beta_{3}$ subunits ameliorates EAE (78). A genetic deficiency or functional blocking of most of the integrins and their ligands have yielded varied results in controlling the disease. These discrepancies might be due to a difference in the induction of EAE models, wherein the contribution of Th1 and Th17 varied to a significant extent. Live cell imaging studies of TEM across ICAM-1 and ICAM-2-deficient brain endothelial monolayers have revealed the presence of an alternative pathway for $\mathrm{CD} 4^{+} \mathrm{T}$ cell diapedesis (79).

Once arrested, $\mathrm{CD} 4^{+} \mathrm{T}$ cells start crawling on inflamed CNS microvessels to search the sites for diapedesis. TEM of CD4 ${ }^{+}$ $\mathrm{T}$ cells across the BBB can occur through both, intercellular junctions and the cell body, known as paracellular and transcellular migration, respectively $(80,81)$. However, the physiological factors that dictate the choice of the transmigration route are not known, and thus forming an active area of investigation. Several studies have demonstrated that during TEM there is a fast and very dynamic remodeling of the endothelial junctional proteins that guide the migration of $\mathrm{CD} 4^{+} \mathrm{T}$ cells through paracellular route (82). The involvement of some of the adhesion molecules and junctional proteins such as PECAM-1, CD99, Claudin-5, VE-cadherin, and JAMs in the regulation of paracellular TEM has been very well studied (83). Upon attachment of the CD4 ${ }^{+}$ $T$ cells to the apical surface of inflamed brain ECs, a rapid clustering of ICAM-1 and VCAM-1 occurs around the transmigrating $\mathrm{CD}^{+} \mathrm{T}$ cells, resulting in the formation of transmigratory cups enriched with actin filaments (84). These clustering events trigger the various signaling pathways, leading to generation of an intracellular calcium flux, phosphorylation of key molecules that regulate the actin cytoskeleton, and production of reactive oxygen and nitric oxide species, which ultimately result in junctional disassembly (85). Numerous factors such as shear force, cytokine-induced inflammatory changes in the brain ECs, type of lymphocytes, and levels of junctional tightness have been hypothesized as the potential factors that regulate transcellular TEM of cells at the BBB. A recent study showed that cytokine-induced increased levels of ICAM-1 on the apical surface of primary mouse brain microvascular cell monolayers promote the transcellular TEM of $\mathrm{CD}^{+} \mathrm{T}$ cells possibly because of high occupancy of its receptor LFA-1 on CD4 $4^{+} \mathrm{T}$ cells $(80,81)$. In addition, overexpression of the C-terminal deletion mutant form of ICAM-1 in primary brain endothelial monolayers inhibits the TEM of leukocytes by reducing transcellular migration (86). Recently, the critical role of the lateral border recycling compartment, a recently identified endothelial specific subcellular compartment (enriched with PECAM-1 and CD99), have been shown to support both paracellular and transcellular TEM (87). The caveolin-rich transmigratory cups that surround the migrating $\mathrm{CD}^{+} \mathrm{T}$ cells have also been associated with transcellular TEM (88). While transcellular migration is impaired in caveolin-1-deficient ECs, they show higher paracellular TEM, suggesting that in the absence of one pathway another route can compensate (88). Similarly, whether a lack of paracellular migration at the endothelial monolayers of high barrier tightness, such as the BBB favors the transcellular route remains to be determined.

After crossing the endothelial vessels of the BBB, CD4 ${ }^{+}$ $\mathrm{T}$ cells encounter the glial (glia limitans) basement membrane, and breaching this acellular structure represents the final step of trafficking into the CNS. The endothelial basement membrane at the $\mathrm{BBB}$ is characterized by the presence of laminin $\alpha_{4}$ and $\alpha_{5}$. It has been demonstrated that encephalitogenic $\mathrm{CD} 4^{+} \mathrm{T}$ cells cross the endothelial basement membrane through $\alpha_{6} \beta_{1}$-integrinlaminin $\alpha_{4}$ interactions (89). On the other hand, laminin $\alpha_{5}$ in the endothelial basement membrane inhibits migration (89). Under physiological conditions, CXCL12 is abundantly expressed on the abluminal surface of brain endothelial microvessels, which inhibits the migration of CXCR4 $4^{+}$leukocytes into the CNS parenchyma (90). The cytokine-induced CXCR7 expression on these endothelial microvessels changes the localization of CXCL12 to the luminal surface, resulting in TEM of CXCR4 ${ }^{+}$leukocytes at the peak of the EAE (91). In contrast to the endothelial basement membrane, the glia limitans is enriched with laminin $\alpha 1$ and $\alpha 2$. Since encephalitogenic $\mathrm{CD} 4^{+} \mathrm{T}$ cells do not interact with laminin $\alpha 1$ and $\alpha 2$, they depend on matrix metalloproteinases (MMPs) to cross the basement membranes. Various types of MMPs, such as MMP-2, MMP-7, MMP-8, and MMP-9, have been identified in the CSF and lesions of MS and EAE. During EAE, MMP2 and MMP9 expression are specifically increased, and their combined action is positively correlated with the migration of $\mathrm{CD}^{+} \mathrm{T}$ cells across glia limitans (92). One of the targets of MMP2 and MMP9 is $\beta$-dystroglycan, a receptor which anchors astrocytic endfeet to the parenchymal basement membrane, leading to secretion of chemokines by the astrocytes at the glia limitans (93). Meningeal inflammation actively controls local $\mathrm{CD}^{+} \mathrm{T}$ cell reactivation and transmigration into the CNS. It has been recently shown that Th17-derived IL-17 and IL-22 activate meningeal stromal cells, which support the de novo IL-17 responses in the meninges (94). Interestingly, a finding has extended our current view about the role of T-bet beyond the generation of pathogenic Th1/Th17 cells and showed that 
T-bet expressing NKp46 ${ }^{+}$innate lymphoid cells (ILCs) promote meningeal inflammation and regulate EAE development by supporting Th17 migration into the CNS (95). Thus, the relay of coordinated signaling induced by cytokines, chemokines, and cell adhesion molecules in the ECs of the BBB and migrating $\mathrm{CD} 4^{+} \mathrm{T}$ cells orchestrate the multistep migration of encephalitogenic $\mathrm{CD}^{+} \mathrm{T}$ cells into the CNS parenchyma.

\section{FUTURE PERSPECTIVE}

Both genetics and environmental factors cooperate to program auto-reactive $\mathrm{CD}^{+}{ }^{+} \mathrm{T}$ cells to perform both pathogenic and regulatory functions during the course of autoimmune CNS pathologies. Recent evidence has suggested that the phenotype and functions of pathogenic Th1, Th17, and regulatory Tregs cells are regulated at various anatomic and physiological levels. The APCs in the periphery, tertiary lymphoid structures, stromal cells, and subsets of ILCs in the meninges, ECs at the BBB, and various CNS resident and infiltrating cells in the CNS parenchyma tightly control the activation, differentiation, and migration of $\mathrm{CD}^{+} \mathrm{T}$ cells that dictate the induction, maintenance, and resolution of autoimmune neuroinflammation. While considerable evidence already links Th1 and Th17 cells to the pathology of CNS autoimmunity, this list of cells continues to grow with recently identified subsets of $\mathrm{CD}^{+} \mathrm{T}$ cells, the IL-9-secreting Th9 cells, and IL-10-secreting Foxp $3^{-} \operatorname{Tr} 1$ cells $(44,96)$. However, the exact role of these cells and their associated molecules on the BBB, CNS resident cells, and other effector and regulatory leukocytes in the inflamed CNS parenchyma, and their overall impact in shaping neuroinflammation warrants further investigation. The ECs of the $\mathrm{BBB}$ have been recently shown to promote antigen-specific Th1 and Th17 migration through myelin-antigen presentation (97). However, the qualitative and quantitative differences in the

\section{REFERENCES}

1. Louveau A, Harris TH, Kipnis J. Revisiting the mechanisms of CNS immune privilege. Trends Immunol (2015) 36(10):569-77. doi:10.1016/j.it.2015.08.006

2. Simmons SB, Pierson ER, Lee SY, Goverman JM. Modeling the heterogeneity of multiple sclerosis in animals. Trends Immunol (2013) 34(8):410-22. doi:10.1016/j.it.2013.04.006

3. Dendrou CA, Fugger L, Friese MA. Immunopathology of multiple sclerosis. Nat Rev Immunol (2015) 15(9):545-58. doi:10.1038/nri3871

4. Olsson T, Barcellos LF, Alfredsson L. Interactions between genetic, lifestyle and environmental risk factors for multiple sclerosis. Nat Rev Neurol (2017) 13(1):25-36. doi:10.1038/nrneurol.2016.187

5. Stromnes IM, Goverman JM. Active induction of experimental allergic encephalomyelitis. Nat Protoc (2006) 1(4):1810-9. doi:10.1038/nprot.2006.285

6. Stromnes IM, Goverman JM. Passive induction of experimental allergic encephalomyelitis. Nat Protoc (2006) 1(4):1952-60. doi:10.1038/nprot. 2006.284

7. Ronchi F, Basso C, Preite S, Reboldi A, Baumjohann D, Perlini L, et al. Experimental priming of encephalitogenic Th1/Th17 cells requires pertussis toxin-driven IL-1beta production by myeloid cells. Nat Commun (2016) 7:11541. doi:10.1038/ncomms11541

8. Blankenhorn EP, Butterfield RJ, Rigby R, Cort L, Giambrone D, McDermott P, et al. Genetic analysis of the influence of pertussis toxin on experimental allergic encephalomyelitis susceptibility: an environmental agent can override genetic checkpoints. JImmunol (2000) 164(6):3420-5. doi:10.4049/jimmunol.164.6.3420 regulation of transmigration of Th1, Th17, Th9, Tregs, and $\operatorname{Tr} 1$ cells across the BBB is not known and needs further attention. Experiments with knockout mice have revealed a great deal of information about the role of $\mathrm{CD}^{+} \mathrm{T}$ cell subsets and their lineage-associated transcription factors, cytokines, and homing receptors in the induction and propagation of CNS inflammation. The complete resistance of EAE in mice that lack T-bet, ROR $\gamma \mathrm{t}$, IL-23R, and GM-CSF is attributed to the absence of pathogenic Th1 and Th17 functions $(21,26)$. However, these molecules are not exclusively expressed in $\mathrm{CD} 4^{+} \mathrm{T}$ cells, and the contribution of other myeloid and lymphoid cells, including subsets of $\gamma \delta$ T cells, ILC1 and ILC3 that express/respond to these molecules, needs to be further investigated. Therefore, to better understand the pathophysiology of $\mathrm{CD} 4^{+} \mathrm{T}$ cells in autoimmune CNS diseases, we need to dissect out the contributions made by the other cell types that share the transcription factors, cytokines, and homing receptors of $\mathrm{CD}^{+} \mathrm{T}$ cell lineages. A reductionist approach may help in probing the exact role of $\mathrm{CD}^{+} \mathrm{T}$ cell subsets through the course of CNS inflammation and autoimmunity.

\section{AUTHOR CONTRIBUTIONS}

SS and GL planned and wrote the manuscript.

\section{FUNDING}

This work was supported by Department of Biotechnology (DBT), Government of India (Grants, BT/PR15533/ MED/30/1616/2015; BT/PR14156/BRB/10/1515/2016; and BT/ PR4610/MED/30/720/2012 to GL). SS received Senior Research Fellowship (SRF) from Council of Scientific and Industrial Research (CSIR), Government of India. Authors also thank Dr. Jyoti Rao for critical reading and edits.

9. Anderton SM. Avoiding autoimmune disease - T cells know their limits Trends Immunol (2006) 27(5):208-14. doi:10.1016/j.it.2006.03.002

10. Cassan C, Piaggio E, Zappulla JP, Mars LT, Couturier N, Bucciarelli F, et al. Pertussis toxin reduces the number of splenic Foxp3+ regulatory $\mathrm{T}$ cells. J Immunol (2006) 177(3):1552-60. doi:10.4049/jimmunol.177.3.1552

11. Bettelli E, Pagany M, Weiner HL, Linington C, Sobel RA, Kuchroo VK. Myelin oligodendrocyte glycoprotein-specific T cell receptor transgenic mice develop spontaneous autoimmune optic neuritis. J Exp Med (2003) 197(9):1073-81. doi:10.1084/jem.20021603

12. Sonar S, Lal G. Role of tumor necrosis factor superfamily in neuroinflammation and autoimmunity. Front Immunol (2015) 6:364. doi:10.3389/ fimmu.2015.00364

13. Yang Y, Weiner J, Liu Y, Smith AJ, Huss DJ, Winger R, et al. T-bet is essential for encephalitogenicity of both Th1 and Th17 cells. J Exp Med (2009) 206(7):1549-64. doi:10.1084/jem.20082584

14. Szabo SJ, Kim ST, Costa GL, Zhang X, Fathman CG, Glimcher LH. A novel transcription factor, T-bet, directs Th1 lineage commitment. Cell (2000) 100(6):655-69. doi:10.1016/S0092-8674(00)80702-3

15. Thieu VT, Yu Q, Chang HC, Yeh N, Nguyen ET, Sehra S, et al. Signal transducer and activator of transcription 4 is required for the transcription factor T-bet to promote T helper 1 cell-fate determination. Immunity (2008) 29(5):679-90. doi:10.1016/j.immuni.2008.08.017

16. Djuretic IM, Levanon D, Negreanu V, Groner Y, Rao A, Ansel KM. Transcription factors T-bet and Runx3 cooperate to activate Ifng and silence Il4 in T helper type 1 cells. Nat Immunol (2007) 8(2):145-53. doi:10.1038/ ni1424 
17. Lazarevic V, Chen X, Shim JH, Hwang ES, Jang E, Bolm AN, et al. T-bet represses $\mathrm{T}(\mathrm{H}) 17$ differentiation by preventing Runx1-mediated activation of the gene encoding RORgammat. Nat Immunol (2011) 12(1):96-104. doi:10.1038/ni.1969

18. Bettelli E, Sullivan B, Szabo SJ, Sobel RA, Glimcher LH, Kuchroo VK. Loss of T-bet, but not STAT1, prevents the development of experimental autoimmune encephalomyelitis. J Exp Med (2004) 200(1):79-87. doi:10.1084/jem.20031819

19. Ferber IA, Brocke S, Taylor-Edwards C, Ridgway W, Dinisco C, Steinman L, et al. Mice with a disrupted IFN-gamma gene are susceptible to the induction of experimental autoimmune encephalomyelitis (EAE). JImmunol (1996) 156(1):5-7.

20. McGeachy MJ, Bak-Jensen KS, Chen Y, Tato CM, Blumenschein W, McClanahan T, et al. TGF-beta and IL-6 drive the production of IL-17 and IL-10 by T cells and restrain T(H)-17 cell-mediated pathology. Nat Immunol (2007) 8(12):1390-7. doi:10.1038/ni1539

21. Stockinger B, Omenetti S. The dichotomous nature of T helper 17 cells. Nat Rev Immunol (2017) 17(9):535-44. doi:10.1038/nri.2017.50

22. Lee Y, Awasthi A, Yosef N, Quintana FJ, Xiao S, Peters A, et al. Induction and molecular signature of pathogenic TH17 cells. Nat Immunol (2012) 13(10):991-9. doi:10.1038/ni.2416

23. Langrish CL, Chen Y, Blumenschein WM, Mattson J, Basham B, Sedgwick JD, et al. IL-23 drives a pathogenic T cell population that induces autoimmune inflammation. J Exp Med (2005) 201(2):233-40. doi:10.1084/jem.20041257

24. Ghoreschi K, Laurence A, Yang XP, Tato CM, McGeachy MJ, Konkel JE, et al. Generation of pathogenic $\mathrm{T}(\mathrm{H}) 17$ cells in the absence of TGF-beta signalling. Nature (2010) 467(7318):967-71. doi:10.1038/nature09447

25. Cua DJ, Sherlock J, Chen Y, Murphy CA, Joyce B, Seymour B, et al. Interleukin-23 rather than interleukin-12 is the critical cytokine for autoimmune inflammation of the brain. Nature (2003) 421(6924):744-8. doi:10.1038/nature01355

26. Gocke AR, Cravens PD, Ben LH, Hussain RZ, Northrop SC, Racke MK, et al. T-bet regulates the fate of Th1 and Th17 lymphocytes in autoimmunity. J Immunol (2007) 178(3):1341-8. doi:10.4049/jimmunol.178.3.1341

27. Kara EE, McKenzie DR, Bastow CR, Gregor CE, Fenix KA, Ogunniyi AD, et al. CCR2 defines in vivo development and homing of IL-23-driven GM-CSFproducing Th17 cells. Nat Commun (2015) 6:8644. doi:10.1038/ncomms9644

28. Grifka-Walk HM, Giles DA, Segal BM. IL-12-polarized Th1 cells produce GM-CSF and induce EAE independent of IL-23. Eur JImmunol (2015) 45(10):2780-6. doi:10.1002/eji.201545800

29. Restorick SM, Durant L, Kalra S, Hassan-Smith G, Rathbone E, Douglas MR, et al. CCR6+ Th cells in the cerebrospinal fluid of persons with multiple sclerosis are dominated by pathogenic non-classic Th1 cells and GM-CSF-only-secreting Th cells. Brain Behav Immun (2017) 64:71-9. doi:10.1016/j.bbi.2017.03.008

30. Murphy KM, Stockinger B. Effector T cell plasticity: flexibility in the face of changing circumstances. Nat Immunol (2010) 11(8):674-80. doi:10.1038/ ni. 1899

31. Wang Y, Godec J, Ben-Aissa K, Cui K, Zhao K, Pucsek AB, et al. The transcription factors T-bet and Runx are required for the ontogeny of pathogenic interferon-gamma-producing T helper 17 cells. Immunity (2014) 40(3):35566. doi:10.1016/j.immuni.2014.01.002

32. Harbour SN, Maynard CL, Zindl CL, Schoeb TR, Weaver CT. Th17 cells give rise to Th1 cells that are required for the pathogenesis of colitis. Proc Natl Acad Sci U S A (2015) 112(22):7061-6. doi:10.1073/pnas.1415675112

33. Gagliani N, Amezcua Vesely MC, Iseppon A, Brockmann L, Xu H, Palm NW, et al. Th17 cells transdifferentiate into regulatory $\mathrm{T}$ cells during resolution of inflammation. Nature (2015) 523(7559):221-5. doi:10.1038/nature14452

34. Sawant DV, Vignali DA. Once a Treg, always a Treg? Immunol Rev (2014) 259(1):173-91. doi:10.1111/imr.12173

35. Lee PW, Smith AJ, Yang Y, Selhorst AJ, Liu Y, Racke MK, et al. IL-23R-activated STAT3/STAT4 is essential for Th1/Th17-mediated CNS autoimmunity. JCI Insight (2017) 2(17):e91663. doi:10.1172/jci.insight.91663

36. Zhou L, Lopes JE, Chong MM, Ivanov II, Min R, Victora GD, et al. TGFbeta-induced Foxp3 inhibits $\mathrm{T}(\mathrm{H}) 17$ cell differentiation by antagonizing RORgammat function. Nature (2008) 453(7192):236-40. doi:10.1038/ nature 06878

37. Lee PW, Severin ME, Lovett-Racke AE. TGF-beta regulation of encephalitogenic and regulatory T cells in multiple sclerosis. Eur J Immunol (2017) 47(3):446-53. doi:10.1002/eji.201646716
38. Lal G, Bromberg JS. Epigenetic mechanisms of regulation of Foxp3 expression.Blood(2009) 114(18):3727-35.doi:10.1182/blood-2009-05-219584

39. Sethi A, Kulkarni N, Sonar S, Lal G. Role of miRNAs in CD4 T cell plasticity during inflammation and tolerance. Front Genet (2013) 4:8. doi:10.3389/ fgene.2013.00008

40. Hori S, Nomura T, Sakaguchi S. Control of regulatory T cell development by the transcription factor Foxp3. Science (2003) 299(5609):1057-61. doi:10.1126/science. 1079490

41. Horwitz DA, Zheng SG, Gray JD. Natural and TGF-beta-induced Foxp3(+) $\mathrm{CD} 4(+) \mathrm{CD} 25(+)$ regulatory $\mathrm{T}$ cells are not mirror images of each other. Trends Immunol (2008) 29(9):429-35. doi:10.1016/j.it.2008.06.005

42. Fontenot JD, Gavin MA, Rudensky AY. Pillars article: Foxp3 programs the development and function of CD4+CD25+ regulatory T cells. Nat Immunol (2017) 4:330-6; J Immunol 198(3):986-92. doi:10.1038/ni904

43. Schmidt A, Oberle N, Krammer PH. Molecular mechanisms of Tregmediated T cell suppression. Front Immunol (2012) 3:51. doi:10.3389/fimmu. 2012.00051

44. Jager A, Dardalhon V, Sobel RA, Bettelli E, Kuchroo VK. Th1, Th17, and Th9 effector cells induce experimental autoimmune encephalomyelitis with different pathological phenotypes. J Immunol (2009) 183(11):7169-77. doi:10.4049/ jimmunol.0901906

45. Johnson D, Seeldrayers PA, Weiner HL. The role of mast cells in demyelination. 1. Myelin proteins are degraded by mast cell proteases and myelin basic protein and P2 can stimulate mast cell degranulation. Brain Res (1988) 444(1):195-8. doi:10.1016/0006-8993(88)90929-8

46. Serafini B, Rosicarelli B, Magliozzi R, Stigliano E, Aloisi F. Detection of ectopic B-cell follicles with germinal centers in the meninges of patients with secondary progressive multiple sclerosis. Brain Pathol (2004) 14(2):164-74. doi:10.1 111/j.1750-3639.2004.tb00049.x

47. Gagliani N, Jofra T, Stabilini A, Valle A, Atkinson M, Roncarolo MG, et al. Antigen-specific dependence of Tr1-cell therapy in preclinical models of islet transplant. Diabetes (2010) 59(2):433-9. doi:10.2337/db09-1168

48. Batten M, Li J, Yi S, Kljavin NM, Danilenko DM, Lucas S, et al. Interleukin 27 limits autoimmune encephalomyelitis by suppressing the development of interleukin 17-producing T cells. Nat Immunol (2006) 7(9):929-36. doi:10.1038/ni1375

49. Gran B, Zhang GX, Yu S, Li J, Chen XH, Ventura ES, et al. IL-12p35-deficient mice are susceptible to experimental autoimmune encephalomyelitis: evidence for redundancy in the IL-12 system in the induction of central nervous system autoimmune demyelination. J Immunol (2002) 169(12):7104-10. doi:10.4049/jimmunol.169.12.7104

50. Zhang GX, Gran B, Yu S, Li J, Siglienti I, Chen X, et al. Induction of experimental autoimmune encephalomyelitis in IL-12 receptor-beta 2-deficient mice: IL-12 responsiveness is not required in the pathogenesis of inflammatory demyelination in the central nervous system. JImmunol (2003) 170(4):2153-60. doi:10.4049/jimmunol.170.4.2153

51. Chitnis T, Najafian N, Benou C, Salama AD, Grusby MJ, Sayegh MH, et al. Effect of targeted disruption of STAT4 and STAT6 on the induction of experimental autoimmune encephalomyelitis. J Clin Invest (2001) 108(5):739-47. doi:10.1172/JCI12563

52. Korner H, Riminton DS, Strickland DH, Lemckert FA, Pollard JD, Sedgwick JD. Critical points of tumor necrosis factor action in central nervous system autoimmune inflammation defined by gene targeting. J Exp Med (1997) 186(9):1585-90. doi:10.1084/jem.186.9.1585

53. Eugster HP, Frei K, Bachmann R, Bluethmann H, Lassmann H, Fontana A. Severity of symptoms and demyelination in MOG-induced EAE depends on TNFR1. Eur J Immunol (1999) 29(2):626-32. doi:10.1002/(SICI)1521-4141 (199902)29:02<626::AID-IMMU626>3.0.CO;2-A

54. Willenborg DO, Staykova M, Fordham S, O’Brien N, Linares D. The contribution of nitric oxide and interferon gamma to the regulation of the neuro-inflammation in experimental autoimmune encephalomyelitis. J Neuroimmunol (2007) 191(1-2):16-25. doi:10.1016/j.jneuroim.2007.09.007

55. Awasthi A, Riol-Blanco L, Jager A, Korn T, Pot C, Galileos G, et al. Cutting edge: IL-23 receptor gfp reporter mice reveal distinct populations of IL-17-producing cells. J Immunol (2009) 182(10):5904-8. doi:10.4049/ jimmunol.0900732

56. Samoilova EB, Horton JL, Hilliard B, Liu TS, Chen Y. IL-6-deficient mice are resistant to experimental autoimmune encephalomyelitis: roles of IL-6 in 
the activation and differentiation of autoreactive T cells. J Immunol (1998) 161(12):6480-6.

57. Codarri L, Gyulveszi G, Tosevski V, Hesske L, Fontana A, Magnenat L, et al. RORgammat drives production of the cytokine GM-CSF in helper T cells, which is essential for the effector phase of autoimmune neuroinflammation. Nat Immunol (2011) 12(6):560-7. doi:10.1038/ni.2027

58. Haak S, Croxford AL, Kreymborg K, Heppner FL, Pouly S, Becher B, et al. IL-17A and IL-17F do not contribute vitally to autoimmune neuroinflammation in mice. J Clin Invest (2009) 119(1):61-9. doi:10.1172/JCI35997

59. Coquet JM, Chakravarti S, Smyth MJ, Godfrey DI. Cutting edge: IL-21 is not essential for Th17 differentiation or experimental autoimmune encephalomyelitis. J Immunol (2008) 180(11):7097-101. doi:10.4049/jimmunol.180.11.7097

60. Sonderegger I, Kisielow J, Meier R, King C, Kopf M. IL-21 and IL-21R are not required for development of Th17 cells and autoimmunity in vivo. Eur J Immunol (2008) 38(7):1833-8. doi:10.1002/eji.200838511

61. Kreymborg K, Etzensperger R, Dumoutier L, Haak S, Rebollo A, Buch T, et al. IL-22 is expressed by Th17 cells in an IL-23-dependent fashion, but not required for the development of autoimmune encephalomyelitis. J Immunol (2007) 179(12):8098-104. doi:10.4049/jimmunol.179.12.8098

62. Alvarez JI, Dodelet-Devillers A, Kebir H, Ifergan I, Fabre PJ, Terouz S, et al. The Hedgehog pathway promotes blood-brain barrier integrity and CNS immune quiescence. Science (2011) 334(6063):1727-31. doi:10.1126/science.1206936

63. Kerfoot SM, Kubes P. Overlapping roles of P-selectin and alpha 4 integrin to recruit leukocytes to the central nervous system in experimental autoimmune encephalomyelitis. J Immunol (2002) 169(2):1000-6. doi:10.4049/ jimmunol.169.2.1000

64. Sathiyanadan K, Coisne C, Enzmann G, Deutsch U, Engelhardt B. PSGL-1 and E/P-selectins are essential for T-cell rolling in inflamed CNS microvessels but dispensable for initiation of EAE. Eur J Immunol (2014) 44(8):2287-94. doi:10.1002/eji.201344214

65. Doring A, Wild M, Vestweber D, Deutsch U, Engelhardt B. E- and P-selectin are not required for the development of experimental autoimmune encephalomyelitis in C57BL/6 and SJL mice. J Immunol (2007) 179(12):8470-9. doi:10.4049/jimmunol.179.12.8470

66. Laschinger M, Engelhardt B. Interaction of alpha4-integrin with VCAM-1 is involved in adhesion of encephalitogenic $\mathrm{T}$ cell blasts to brain endothelium but not in their transendothelial migration in vitro. J Neuroimmunol (2000) 102(1):32-43. doi:10.1016/S0165-5728(99)00156-3

67. Holman DW, Klein RS, Ransohoff RM. The blood-brain barrier, chemokines and multiple sclerosis. Biochim Biophys Acta (2011) 1812(2):220-30. doi:10.1016/j.bbadis.2010.07.019

68. Chen SC, Leach MW, Chen Y, Cai XY, Sullivan L, Wiekowski M, et al. Central nervous system inflammation and neurological disease in transgenic mice expressing the CC chemokine CCL21 in oligodendrocytes. J Immunol (2002) 168(3):1009-17. doi:10.4049/jimmunol.168.3.1009

69. Wildbaum G, Netzer N, Karin N. Plasmid DNA encoding IFN-gammainducible protein 10 redirects antigen-specific $\mathrm{T}$ cell polarization and suppresses experimental autoimmune encephalomyelitis. J Immunol (2002) 168(11):5885-92. doi:10.4049/jimmunol.168.11.5885

70. Steffen BJ, Butcher EC, Engelhardt B. Evidence for involvement of ICAM-1 and VCAM-1 in lymphocyte interaction with endothelium in experimental autoimmune encephalomyelitis in the central nervous system in the SJL/J mouse. Am J Pathol (1994) 145(1):189-201.

71. Greenwood J, Wang Y, Calder VL. Lymphocyte adhesion and transendothelial migration in the central nervous system: the role of LFA-1, ICAM-1, VLA-4 and VCAM-1. Immunology (1995) 86(3):408-15.

72. Hutchinson M. Natalizumab: a new treatment for relapsing remitting multiple sclerosis. Ther Clin Risk Manag (2007) 3(2):259-68. doi:10.2147/ tcrm.2007.3.2.259

73. Rothhammer V, Heink S, Petermann F, Srivastava R, Claussen MC, Hemmer B, et al. Th17 lymphocytes traffic to the central nervous system independently of alpha4 integrin expression during EAE. J Exp Med (2011) 208(12):2465-76. doi:10.1084/jem.20110434

74. Glatigny S, Duhen R, Oukka M, Bettelli E. Cutting edge: loss of alpha4 integrin expression differentially affects the homing of Th1 and Th17 cells. J Immunol (2011) 187(12):6176-9. doi:10.4049/jimmunol.1102515

75. Larochelle C, Cayrol R, Kebir H, Alvarez JI, Lecuyer MA, Ifergan I, et al. Melanoma cell adhesion molecule identifies encephalitogenic $\mathrm{T}$ lymphocytes and promotes their recruitment to the central nervous system. Brain (2012) 135(Pt 10):2906-24. doi:10.1093/brain/aws212

76. Cayrol R, Wosik K, Berard JL, Dodelet-Devillers A, Ifergan I, Kebir H, et al. Activated leukocyte cell adhesion molecule promotes leukocyte trafficking into the central nervous system. Nat Immunol (2008) 9(2):137-45. doi:10.1038/ ni1551

77. Larochelle C, Lecuyer MA, Alvarez JI, Charabati M, Saint-Laurent O, Ghannam S, et al. Melanoma cell adhesion molecule-positive CD8 T lymphocytes mediate central nervous system inflammation. Ann Neurol (2015) 78(1):39-53. doi:10.1002/ana.24415

78. Du F, Garg AV, Kosar K, Majumder S, Kugler DG, Mir GH, et al. Inflammatory Th17 cells express integrin alphavbeta 3 for pathogenic function. Cell Rep (2016) 16(5):1339-51. doi:10.1016/j.celrep.2016.06.065

79. Steiner O, Coisne C, Cecchelli R, Boscacci R, Deutsch U, Engelhardt B, et al. Differential roles for endothelial ICAM-1, ICAM-2, and VCAM-1 in shear-resistant $\mathrm{T}$ cell arrest, polarization, and directed crawling on bloodbrain barrier endothelium. J Immunol (2010) 185(8):4846-55. doi:10.4049/ jimmunol.0903732

80. Abadier M, Haghayegh Jahromi N, Cardoso Alves L, Boscacci R, Vestweber D, Barnum S, et al. Cell surface levels of endothelial ICAM-1 influence the transcellular or paracellular T-cell diapedesis across the blood-brain barrier. Eur J Immunol (2015) 45(4):1043-58. doi:10.1002/eji.201445125

81. Sonar SA, Shaikh S, Joshi N, Atre AN, Lal G. IFN-gamma promotes transendothelial migration of CD4+ T cells across the blood-brain barrier. Immunol Cell Biol (2017) 95:843-53. doi:10.1038/icb.2017.56

82. Winger RC, Koblinski JE, Kanda T, Ransohoff RM, Muller WA. Rapid remodeling of tight junctions during paracellular diapedesis in a human model of the blood-brain barrier. J Immunol (2014) 193(5):2427-37. doi:10.4049/ jimmunol.1400700

83. Muller WA. Transendothelial migration: unifying principles from the endothelial perspective. Immunol Rev (2016) 273(1):61-75. doi:10.1111/imr.12443

84. Carman CV, Springer TA. A transmigratory cup in leukocyte diapedesis both through individual vascular endothelial cells and between them. J Cell Biol (2004) 167(2):377-88. doi:10.1083/jcb.200404129

85. Martinelli R, Gegg M, Longbottom R, Adamson P, Turowski P, Greenwood J. ICAM-1-mediated endothelial nitric oxide synthase activation via calcium and AMP-activated protein kinase is required for transendothelial lymphocyte migration. Mol Biol Cell (2009) 20(3):995-1005. doi:10.1091/mbc. E08-06-0636

86. Yang L, Froio RM, Sciuto TE, Dvorak AM, Alon R, Luscinskas FW. ICAM-1 regulates neutrophil adhesion and transcellular migration of TNF-alphaactivated vascular endothelium under flow. Blood (2005) 106(2):584-92. doi:10.1182/blood-2004-12-4942

87. Mamdouh Z, Mikhailov A, Muller WA. Transcellular migration of leukocytes is mediated by the endothelial lateral border recycling compartment. J Exp Med (2009) 206(12):2795-808. doi:10.1084/jem.20082745

88. Millan J, Hewlett L, Glyn M, Toomre D, Clark P, Ridley AJ. Lymphocyte transcellular migration occurs through recruitment of endothelial ICAM-1 to caveola- and F-actin-rich domains. Nat Cell Biol (2006) 8(2):113-23. doi: $10.1038 /$ ncb 1356

89. Wu C, Ivars F, Anderson P, Hallmann R, Vestweber D, Nilsson P, et al. Endothelial basement membrane laminin alpha5 selectively inhibits T lymphocyte extravasation into the brain. Nat Med (2009) 15(5):519-27. doi:10.1038/nm.1957

90. McCandless EE, Wang Q, Woerner BM, Harper JM, Klein RS. CXCL12 limits inflammation by localizing mononuclear infiltrates to the perivascular space during experimental autoimmune encephalomyelitis. JImmunol (2006) 177(11):8053-64. doi:10.4049/jimmunol.177.11.8053

91. Cruz-Orengo L, Holman DW, Dorsey D, Zhou L, Zhang P, Wright M, et al. CXCR7 influences leukocyte entry into the CNS parenchyma by controlling abluminal CXCL12 abundance during autoimmunity. JExp Med (2011) 208(2):327-39. doi:10.1084/jem.20102010

92. Song J, Wu C, Korpos E, Zhang X, Agrawal SM, Wang Y, et al. Focal MMP-2 and MMP-9 activity at the blood-brain barrier promotes chemokine-induced leukocyte migration. Cell Rep (2015) 10(7):1040-54. doi:10.1016/j. celrep.2015.01.037

93. Agrawal S, Anderson P, Durbeej M, van Rooijen N, Ivars F, Opdenakker G, et al. Dystroglycan is selectively cleaved at the parenchymal basement membrane 
at sites of leukocyte extravasation in experimental autoimmune encephalomyelitis. J Exp Med (2006) 203(4):1007-19. doi:10.1084/jem.20051342

94. Pikor NB, Astarita JL, Summers-Deluca L, Galicia G, Qu J, Ward LA, et al. Integration of Th17- and lymphotoxin-derived signals initiates meningealresident stromal cell remodeling to propagate neuroinflammation. Immunity (2015) 43(6):1160-73. doi:10.1016/j.immuni.2015.11.010

95. Kwong B, Rua R, Gao Y, Flickinger J Jr, Wang Y, Kruhlak MJ, et al. T-betdependent NKp46+ innate lymphoid cells regulate the onset of TH17-induced neuroinflammation. Nat Immunol (2017) 18:1117-27. doi:10.1038/ni.3816

96. Wildbaum G, Netzer N, Karin N. Trl cell-dependent active tolerance blunts the pathogenic effects of determinant spreading. J Clin Invest (2002) 110(5):701-10. doi:10.1172/JCI15176

97. Lopes Pinheiro MA, Kamermans A, Garcia-Vallejo JJ, van Het Hof B, Wierts L, O'Toole $\mathrm{T}$, et al. Internalization and presentation of myelin antigens by the brain endothelium guides antigen-specific $\mathrm{T}$ cell migration. Elife (2016) 5:e13149. doi:10.7554/eLife.13149

Conflict of Interest Statement: The authors declare that the research was conducted in the absence of any commercial or financial relationships that could be construed as a potential conflict of interest.

Copyright (C) 2017 Sonar and Lal. This is an open-access article distributed under the terms of the Creative Commons Attribution License (CC BY). The use, distribution or reproduction in other forums is permitted, provided the original author(s) or licensor are credited and that the original publication in this journal is cited, in accordance with accepted academic practice. No use, distribution or reproduction is permitted which does not comply with these terms. 